\title{
PENGARUH ASAM KUAT, PENGAMPLASAN, DAN LAMA PERENDAMAN TERHADAP LAJU IMBIBISI DAN PERKECAMBAHAN BIJI AREN (Arenga pinnata)
}

\section{THE EFFECT OF STRONG ACID, SANDING AND SOAKING TIME ON THE IMBIBITION AND SEEDLING RATE OF AREN SEED (Arenga pinnata)}

\author{
Marina Silalahi* \\ Prodi Pendidikan Biologi, Fakultas Keguruan dan Ilmu Pendidikan, Universitas Kristen Indonesia, Cawang, Jakarta \\ *Corresponding author: marina_biouki@yahoo.com
}

Naskah Diterima: 3 Januari 2017; Direvisi: 9 Februari 2017; Disetujui: 12 Mei 2017

\begin{abstract}
Abstrak
Biji Arenga pinnata memiliki kulit biji keras dan berlignin sehingga menghambat masuknya air ke dalam biji. Lapisan lignin pada kulit biji dapat didegradasi melalui reaksi kimia maupun perlakuan fisik. Perendaman biji aren dengan asam kuat $\left(\mathrm{HNO}_{3}, \mathrm{H}_{2} \mathrm{SO}_{4}\right.$, dan $\left.\mathrm{HCl}\right)$ dan pengamplasan akan mempengaruhi laju imbibisi air melewati kulit biji. Variabel bebas dalam penelitian ini adalah konsentrasi asam kuat $\left(\mathrm{HNO}_{3}, \mathrm{H}_{2} \mathrm{SO}_{4}\right.$, dan $\left.\mathrm{HCl}\right)$, luas pengamplasan, air panas, lama perendaman, sedangkan variabel terikat laju imbibisi pada biji aren. Konsentrasi asam kuat yang digunakan adalah $1 \mathrm{M}$ dan $0,5 \mathrm{M}$ untuk masing-masing $\mathrm{HNO}_{3}, \mathrm{H}_{2} \mathrm{SO}_{4}$, dan $\mathrm{HCl}$. Pengamplasan dilakukan di bagian pangkal biji, dan luas pengamplasan bervariasi (tanpa amplas, amplas $1 / 2$ bagian, dan amplas keseluruhan). Setiap perlakuan direndam selama 18, 24 dan 36 jam. Biji aren yang diberi perlakuan fisik maupun kimia mengalami pengelupasan kulit biji. Laju imbibisi biji pada perendaman 24 jam lebih tinggi dibandingkan dengan lama perendaman 18 maupun 36 jam. Laju imbibisi tertinggi terjadi pada waktu perendaman $1 \mathrm{M} \mathrm{HCl}$ dan amplas penuh dengan lama perendaman 24 jam sebesar $0,038 \pm 0,002 \mathrm{~mL} / \mathrm{jam}$ dan 0,038 $\pm 0,007 \mathrm{~mL} / \mathrm{jam}$. Biji aren yang diberi perlakuan fisik dan kimia mulai berkecambah 7 minggu setelah tanam dengan daya kecambah tertinggi pada pemberian $\mathrm{HNO}_{3}$ dan lama perendaman 18 jam.
\end{abstract}

Kata kunci: Arenga pinnata; Asam kuat; Imbibisi

\section{Abstract}

Arenga pinnata seed has a hard seed coat and lignin that inhibit the absorption of water into the seed. The lignin in the seed coat can be degraded by chemical or physical treatments. Soaking of the palm seeds into strong acids $\left(\mathrm{HNO}_{3}, \mathrm{H}_{2} \mathrm{SO}_{4}\right.$, or $\left.\mathrm{HCl}\right)$ and sanding may affect the imbibition rate. The research was conducted to investigate the effect of a strong acid, sanding, and soaking time to the imbibition rate of $A$. pinnata seed. The independent variables in this research are concentration of the strong acids $\mathrm{HNO}_{3}, \mathrm{H}_{2} \mathrm{SO}_{4}$, and $\mathrm{HCl}$; sanding, and soaking time, while the dependent variable is the rate of imbibition of A. pinnata Merr. The concentrations of the strong acid used were $1 M$ and 0.5M. The sanding was performed on the base of seeds, which were varied into without sanding, 1/2 parts, and full sanding). The soaking durations were for 18, 24 and 36 hours. Palm sugar seeds treated by physical or chemical showed damage of the skin seeds. The seeds soaked with strong acid absorbed more water than the sanding and control treatments. The rate of imbibition for a 24-hour soaking showed imbibition rate higher than the 18 or 36-hour soaking. The highest rates of imbibition occurred on the treatments of $1 \mathrm{M} \mathrm{HCl}$ soaking and 24 hours full sanding which were $0.038 \pm 0.002 \mathrm{~mL} / \mathrm{h}$ and $0.038 \pm 0.007 \mathrm{~mL} / \mathrm{h}$, respectively. The seeds by physical and chemical treatments started their germination in seven weeks after planting with the highest germination from the treatments of $\mathrm{HNO}_{3}$ and 18 hours soaking time.

Keywords: Arenga pinnata; Imbibition; Strong acids

Permalink/DOI: http//:dx.doi.org/10.15408/kauniyah.v10i2.4758 


\section{PENDAHULUAN}

Aren (Arenga pinnata) merupakan salah satu jenis palem yang sangat potensial untuk dibudidayakan pada masa yang akan datang, karena memiliki nilai ekonomis yang tinggi. Bagi masyarakat Indonesia, aren memiliki nilai ekologi (Tamrin et al., 2015), ekonomi, dan kultural (Ferita et al., 2015; Tamrin et al., 2015). Bidang ekonomi, aren dimanfaatkan sebagai penghasil nira (bahan utama gula, wine, cuka, dan alkohol), sumber energi terbarukan (bioetanol), sumber karbohidrat (tepung), bahan campuran makanan dan minuman (kolang-kaling), bahan bangunan (batang), tanaman konservasi untuk lahan kritis (Ferita et al., 2015; Martini et al., 2016), dan sumber pakan hewan. Hal tersebut mengakibatkan aren digolongkan sebagai Multi Purposes Trees Species (MPTS) (Tamrin et al., 2015).

Salah satu hambatan utama dalam regenerasi aren adalah masa dormansi aren yang relatif panjang dan memiliki daya kecambah yang relatif rendah. Hasil penelitian menunjukkan bahwa daya berkecambah sangat rendah dan beragam (10-65\%), dan waktu yang diperlukan untuk memulai berkecambah cukup lama yakni sekitar 4-6 bulan (Mashud et al., 1989). Waktu yang diperlukan oleh biji untuk berkecambah disebut dengan masa dormansi. Masa dormansi pada tumbuhan dipengaruhi oleh genetik, lingkungan, dan hormon (Koorneef et al., 2002; Nasren et al., 2002; Finch-Savage \& Leubner-Metzger 2006; Graeber et al., 2012). Hormon asam absisat (ABA) dan asam giberelin (GA) merupakan hormon yang paling berperan untuk mengatur perkecambahan (Koorneef et al., 2002; Graeber et al., 2012). ABA akan meningkat ketika tumbuhan mengalami stress seperti kekurangan kadar air (Cutler dan Krochko, 1999).

Berbagai cara telah dilaporkan untuk mematahkan atau mengurangi masa dormansi yaitu dengan meningkatkan konsentrasi air pada biji melalui perendaman dengan asam kuat dan pengamplasan (Saleh, 2004; Ali et al., 2011). Perendaman biji Rhynchosia capitata (Fabaceae) dengan asam kuat $\left(\mathrm{KNO}_{3}, \mathrm{HCl}\right.$, $\mathrm{HNO}_{3}$, dan $\mathrm{H}_{2} \mathrm{SO}_{4}$ ) mampu meningkatkan laju imbibisi sehingga memperpendek masa dormansi dan merangsang perkecambahan biji
(Ali et al., 2011). Selain faktor hormon, struktur biji juga memengaruhi masa dormansi (Saleh, 2004). Widyawati et al., (2009) menyatakan bahwa biji aren merupakan biji keras dengan testa yang tersusun dari jaringan sklereid yang dilapisi oleh lignin. Lignin merupakan senyawa yang bersifat impermiabel sehingga mencegah masuknya air ke dalam embrio biji.

Untuk mengurangi impermiabilitas testa terhadap air berbagai cara dilakukan yaitu dengan cara mekanis maupun dengan cara kimiawi. Cara mekanis dapat dilakukan dengan merusak jaringan testa melalui pengamplasan (Saleh, 2004; Abubakar \& Maimuna, 2013; Widyawati et al., 2015). Pengamplasan dilakukan untuk mengurangi lapisan lignin pada testa sedangkan perendaman dengan asam kuat diduga akan memutuskan ikatan lignin pada testa. Rusaknya lapisan lignin pada testa akan meningkatkan permiabilitas testa terhadap air sehingga memudahkan masuknya air ke dalam embrio. Cara kimiawi dapat dilakukan dengan cara merendam biji dalam larutan asam pekat (Lasut, 2012; Abubakar \& Maimuna, 2013).

Berbagai laporan penelitian menyatakan bahwa biji aren yang telah melewati saluran pencernaan musang merupakan benih yang potensial (Lasut, 2012). Musang memakan buah aren kemudian biji akan dikeluarkan bersama-sama dengan feses. Biji aren yang telah dimakan musang memiliki daya kecambah yang lebih tinggi dengan waktu dormansi yang lebih pendek (Lasut, 2012). Hal tersebut diduga adanya enzim atau senyawa kimia yang terdapat dalam saluran pencernaan musang yang melisis jaringan endocarp biji aren. Senyawa tersebut diduga adalah senyawa asam khususnya ketika biji aren melewati lambung musang.

Salah satu faktor yang mengakibatkan dormansi karena terhambatnya proses penyerapan air oleh adanya jaringan penghalang pada biji seperti eksokarp. Asam kuat telah lama digunakan untuk memutus ikatan jaringan pada kulit luar biji Fabaceae di antaranya $\mathrm{HNO}_{3}, \mathrm{HCl}, \mathrm{H}_{2} \mathrm{SO}_{4}$ (Cavalheiro et al., 2007; Ali et al., 2011). Pengikisan struktur kulit luar biji aren secara mekanik maupun kiamiawi diduga akan mempercepat laju penyerapan air (imbibisi) yang berimplikasi 
pada pematahan masa dormansi sehingga biji masuk ke dalam masa perkecambahan. Hingga saat ini penelitian pemanfaatan asam kuat dikombinasikan dengan pengamplasan belum banyak dilakukan. Berdasarkan hal tersebut, penelitian ini bertujuan mengetahui pengaruh asam kuat $\left(\mathrm{HNO}_{3}, \mathrm{HCl}, \mathrm{H}_{2} \mathrm{SO}_{4}\right)$ terhadap laju imbibisi biji aren. Hasil penelitian ini diharapkan dapat melengkapi data mpeningkatan laju imbibisi biji aren maupun tanaman lainnya, sehingga masa dormansi biji dapat diperpendek.

\section{MATERIAL DAN METODE \\ Bahan dan Sampel Penelitian}

Biji Aren diperoleh dari desa Bah Bolon Tongah, Kecamatan Panei, Sumatera Utara terletak pada ketinggian 600-700 m dpl.

\section{Cara Kerja}

Biji aren yang digunakan dalam penelitian ini merupakan biji yang telah tua bewarna coklat kehitaman. Biji tersebut diperoleh dari buah yang berwarna kuning kemerahan. Kulit buah dibuang, kemudian biji dikeringkan selama 1 bulan di bawah panas matahari. Biji aren kering yang digunakan dalam penelitian ini memiliki berat kering antara 3,90-5,56 g. Perlakuan dilakukan dengan perendaman pada asam kuat (terdiri dari $0,5 \mathrm{M} \mathrm{HCl}, 1 \mathrm{M} \mathrm{HCl}, 0,5 \mathrm{M} \mathrm{HNO}_{3}, 1 \mathrm{M}$ $\mathrm{HNO}_{3}, 0,5 \mathrm{M} \mathrm{H}_{2} \mathrm{SO}_{4}$, dan $\left.1 \mathrm{M} \mathrm{H}_{2} \mathrm{SO}_{4}\right)$, pengamplasan (tanpa diamplas/ kontrol, amplas setengah bagian, amplas keseluruhan) dan perendaman dengan air panas. Pengamplasan dilakukan pada perlakuan pada bagian pangkal biji aren. Masing-masing perlakuan direndam selama 18, 24 dan 36 jam.

Laju imbibisi ini dihitung berdasarkan persamaan sebagai berikut (Miranda et al., 2010):

Lajuimbibisi $=\frac{\text { Berat awal }- \text { Berat setelah perendaman }}{\text { waktu perendaman }}$

Biji yang telah direndam ditanaman pada polibag dengan media campuran tanah: kompos: pasir (1:1:1). Pengamatan dilakukan selama 10 minggu.

\section{Analisis Data}

Analisis data menggunakan SPSS versi 17 meliputi rata-rata laju imbibisi pada masing-masing perlakuan.

\section{HASIL}

\section{Penyerapan Air pada Biji Aren}

Biji aren yang direndam dengan asam kuat $\left(\mathrm{H}_{2} \mathrm{SO}_{4}, \mathrm{HNO}_{3}, \mathrm{HCl}\right)$ mengalami perubahan struktur pada kulit biji. Kulit biji aren yang direndam dengan asam kuat warnanya lebih gelap dan terjadi pengelupasan. Perubahan warna kulit dan pengelupasan kulit biji bervariasi tergantung pada jenis dan konsentrasi asam kuat yang digunakan. Secara visual terlihat bahwa kulit biji yang direndam pada konsentrasi asam kuat yang lebih pekat (1 M) memiliki warna yang lebih gelap dibandingkan konsentrasi yang lebih encer $(0,5$ M). Luas pengelupasan kulit biji yang direndam dengan $\mathrm{H}_{2} \mathrm{SO}_{4}$ lebih tinggi dibandingkan dengan $\mathrm{HCl}$ dan $\mathrm{HNO}_{3}$ (Gambar 1). Kulit biji aren yang direndan dengan air panas juga mengalami perngelupasan, namun kerusakannya relatif lebih sedikit dibandingkan dengan dengan biji yang direndam dengan asam kuat (Gambar 1.D).

Perubahan struktur fisik biji aren berpengaruh terhadap kemampuan biji untuk menyerap air. Besarnya volume air yang masuk ke dalam biji diukur dengan menimbang berat biji sebelum direndam dan setelah direndam. Berhubung massa jenis air sama dengan volume air yang diserap oleh biji karena massa jenis air sebesar 1. Gambar 2 merupakan diagram batang volume air yang dapat diserap oleh biji aren pada berbagai perlakuan dan waktu perendaman. Jumlah volume air yang diserap oleh biji aren bervariasi tergantung pada jenis perlakuan dan lama perendaman.

Pada perendaman 18 jam volume air yang masuk ke dalam biji aren sebesar 0,06 (kontrol)-0,69 mL (1 $\left.\mathrm{M} \mathrm{HNO}_{3}\right)$. Volume air yang masuk ke dalam biji aren paling banyak terdapat pada perlakuan $1,0 \mathrm{M} \mathrm{HNO}_{3}(0,69$ $\mathrm{mL})$, diikuti dengan $0,5 \mathrm{M} \mathrm{HNO}_{3}(0,54 \mathrm{~mL})$, dan $1 \mathrm{M} \mathrm{H}_{2} \mathrm{SO}_{4}(0,47 \mathrm{~mL})$, sedangkan yang paling kecil pada pengamplasan $1 / 2$ bagian $(0,29 \mathrm{~mL})$ dan kontrol $(0,06 \mathrm{~mL})$. Pada perlakuan dengan asam kuat volume air yang masuk ke dalam biji berbanding lurus dengan konsentrasi asam kuat yang digunakan. Hal tersebut menunjukkan bahwa volume air yang masuk ke dalam biji yang direndam pada konsentrasi $1 \mathrm{M}$ lebih banyak dibandingkan volume air yang masuk pada konsentrasi $0,5 \mathrm{M}$ 
pada ketiga jenis asam kuat yang digunakan. Bila dibandingkan antara gambar 1 ternyata besarnya kerusakan kulit luar tidak selalu sebanding dengan volume air yang masuk ke dalam biji. Pengelupasan kulit biji yang direndam dengan $\mathrm{H}_{2} \mathrm{SO}_{4}$ lebih besar dibandingkan dengan $\mathrm{HCl}$ maupun $\mathrm{HNO}_{3}$, namun volume air yang masuk ke dalam biji yang direndam dengan $\mathrm{HNO}_{3}$ lebih banyak dibandingkan dengan $\mathrm{H}_{2} \mathrm{SO}_{4}$.

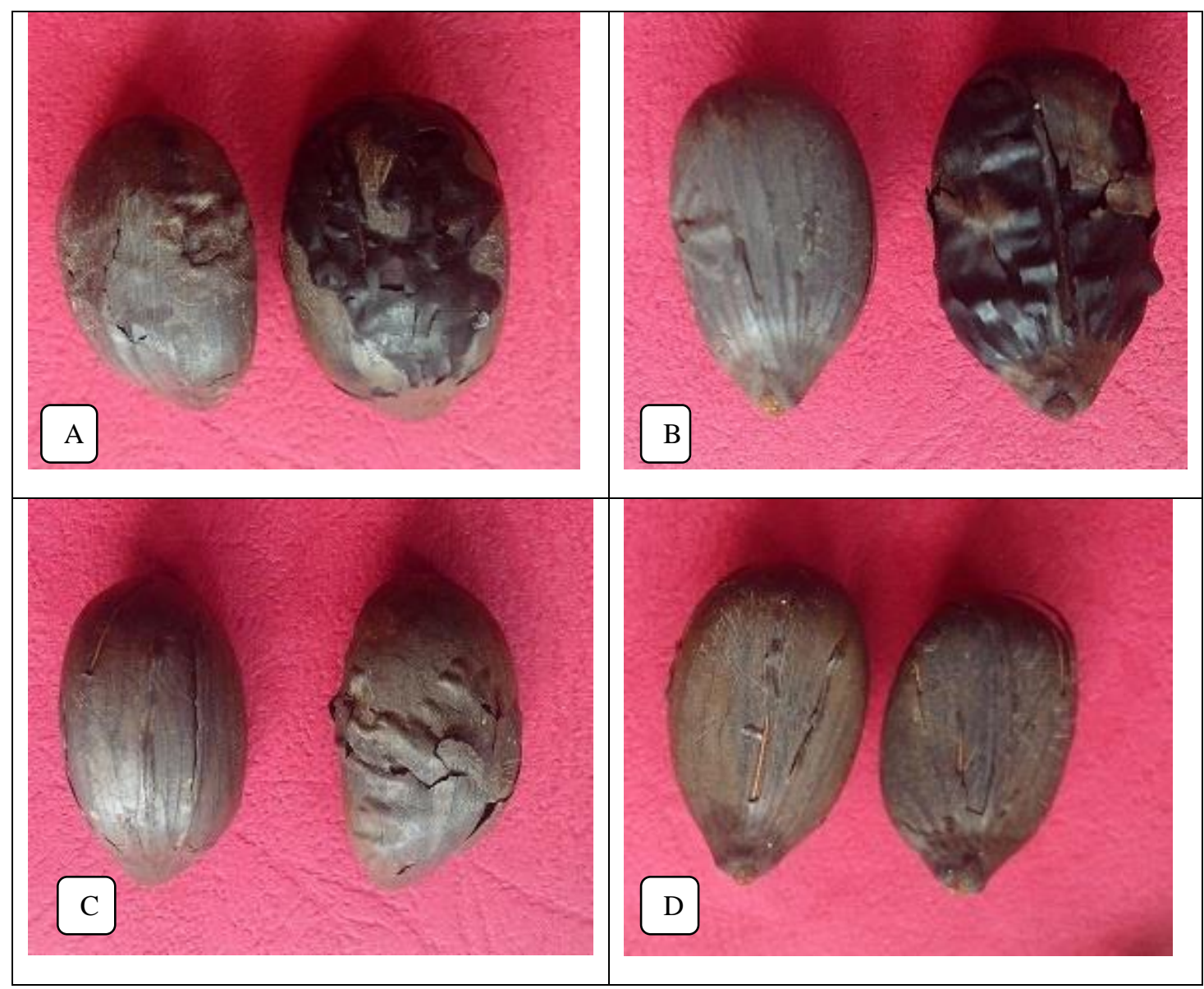

Gambar 1. Perubahan warna dan pengelupasan kulit biji aren yang diberi dengan berbagai perlakuan. A. direndam dengan $\mathrm{H}_{2} \mathrm{SO}_{4}$; B. direndam dengan $\mathrm{HCl}$; C. direndam dengan $\mathrm{HNO}_{3}$; D. direndam dengan air panas. Untuk $\mathrm{A}, \mathrm{B}$, dan $\mathrm{C}$ sebelah kiri direndam dengan 0,5 $\mathrm{M}$ sedangkan sebelah kanannya direndam dengan $1 \mathrm{M}$

Volume air yang masuk ke dalam biji yang direndam dengan air panas (air mendidih) setelah 18 jam perendaman relatif lebih tinggi dibandingkan dengan biji yang diamplas. Volume air yang masuk ke dalam biji yang direndam dengan air panas sebesar $0,40 \mathrm{~mL}$ memiliki volume yang hampir sama dengan biji yang direndam dengan $0,5 \mathrm{M} \mathrm{HCl}(0,41$ $\mathrm{mL})$ dan $0,5 \mathrm{M} \mathrm{H}_{2} \mathrm{SO}_{4}(0,39 \mathrm{~mL})$. Hal ini menunjukkan bahwa air panas merupakan salah satu cara alami yang dapat digunakan untuk mempercepat masuknya air ke dalam biji, khususnya biji yang memiliki struktur kulit luar yang sangat keras. Perendaman biji dengan berbagai asam kuat dengan air panas diduga akan memutus ikatan lignin pada kulit biji. Putusnya ikatan tersebut akan menghasilkan celah-celah atau pori yang lebih mudah ditembus air dibandingkan yang lainnya.

Volume air yang masuk pada biji yang diberi perlakuan fisik (pengamplasan) tidak jauh berbeda yaitu $0,32 \mathrm{~mL}$ pada biji yang diamplas penuh sebesar sedangkan yang diamplas hanya $1 / 2$ bagian $(0,29 \mathrm{~mL})$, namun volume tersebut jauh lebih banyak dibandingkan dengan kontrol $(0,1 \mathrm{~mL})$. Hal tersebut menunjukkan bahwa perbedaan ukuran pengamplas tidak terlalu berpengaruh terhadap masuknya air ke dalam biji. Dalam penelitian ini biji dengan pengamplasan setengah dilakukan pada bagian pangkal dari biji. 
Volume air yang masuk ke dalam biji aren pada semua perlakuan setelah direndam selama 24 jam dan 36 jam, secara umum memiliki pola yang hampir sama lama perendaman pada 18 jam. Biji yang direndam dengan asam kuat menyerap air lebih banyak dibandingkan dengan perlakuan lainnya. Pada lama perendaman 36 jam, biji aren yang direndam dengan $1 \mathrm{M} \mathrm{HNO}_{3}$ mampu menyerap air hingga $0,89 \mathrm{~mL}$ sedangkan paling sedikit terdapat pada kontrol $(0,21 \mathrm{~mL})$. Hal tersebut menunjukkan bahwa volume air yang masuk ke dalam biji yang direndam dengan senyawa kimia lebih tinggi dibandingkan dengan perlakuan lainnya. Hal yang sama terjadi pada lama perendaman 36 jam. Secara konsinsten terlihat bahwa biji yang direndam dengan $\mathrm{HNO}_{3}$ memiliki volume menyerapan air lebih banyak dibanding dengan perlakuan lainnya yaitu sebesar $0,96 \mathrm{~mL}$ air. Volume air yang masuk ke dalam biji pada kontrol yaitu sebesar $0,36 \mathrm{~mL}$.

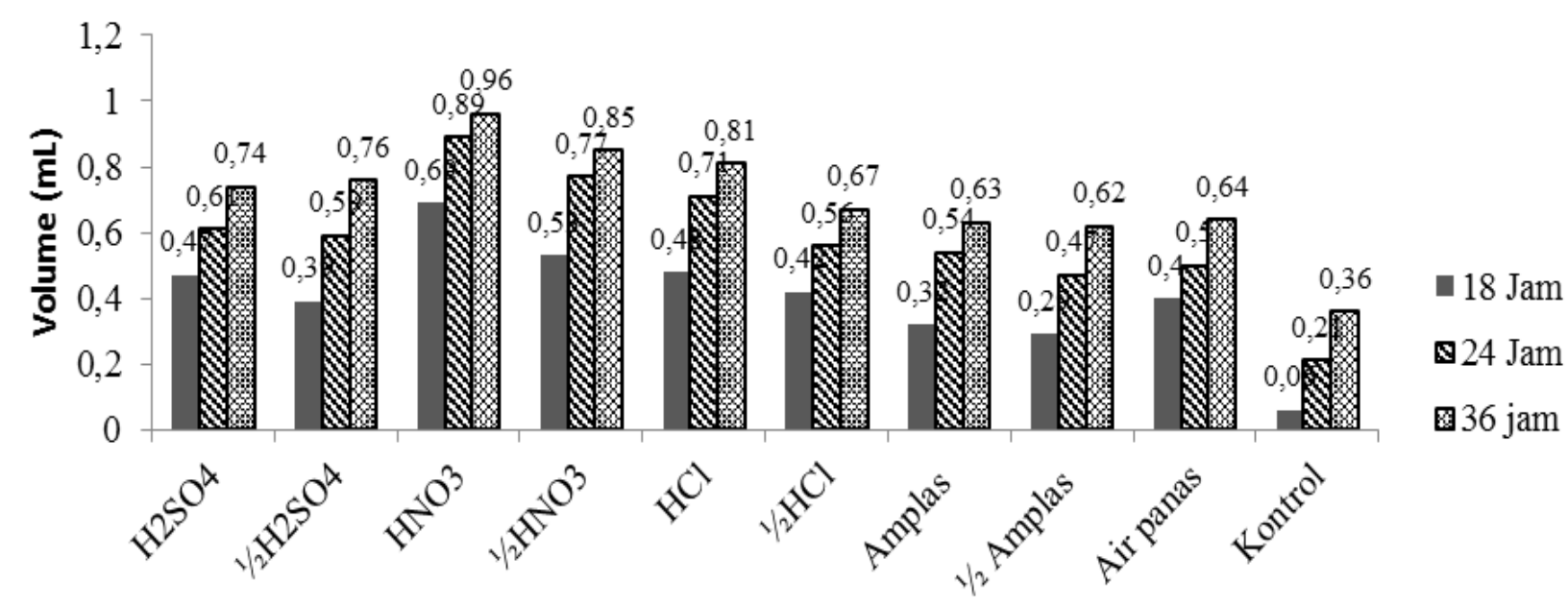

Perlakuan

Gambar 2. Rata-rata volume air yang diserap oleh biji aren dengan berbagai perlakuan dan berbagai waktu perendaman

\section{Laju Imbibisi Biji Aren}

Gambar 3 menunjukkan laju imbibisi pada biji aren dengan berbagai perlakuan dan berbagai waktu perendaman. Laju imbibisi (mL/jam) biji aren pada berbagai perlakuan sebesar 0,003 mL/jam hingga 0,038 mL/jam. Pada awal perendaman atau pada saat perendaman 18 jam laju imbibisi sebesar 0,003 $\mathrm{mL} / \mathrm{jam}$ (kontrol) hingga $0,014 \mathrm{~mL} / \mathrm{jam}(0,5 \mathrm{M}$ $\mathrm{H}_{2} \mathrm{SO}_{4}$ ). Hal tersebut menunjukkan bahwa perbedaan perlakuan memberikan pengaruh yang berbeda-beda terhadap kemampuan biji aren untuk menyerap air.

Pada perendaman 24 jam laju imbibisi meningkat dibandingkan dengan laju imbibisi pada perendaman 18 jam. Laju imbibisi air pada perendaman 24 jam yaitu $0,17 \mathrm{~mL} / \mathrm{jam}$ (air panas) hingga $0,083 \mathrm{~mL} / \mathrm{jam}(1 \mathrm{M} \mathrm{HCl}$ dan $1 \mathrm{M} \mathrm{HNO}_{3}$ ). Secara umum laju imbibisi air pada biji yang direndam dengan asam kuat lebih tinggi dibandingkan dengan perlakuan lainnya. Pada perendaman 18 jam $\mathrm{HNO}_{3}$ me- miliki laju imbibisi lebih tinggi dibandingkan dengan $\mathrm{H}_{2} \mathrm{SO}_{4}$ maupun $\mathrm{HCl}$ sedangkan pada perendaman 24 jam $\mathrm{HCl}$ lebih tinggi dibandingkan dengan $\mathrm{H}_{2} \mathrm{SO}_{4}$ dan $\mathrm{HNO}_{3}$.

Perlakuan fisik dengan pengamplasan memiliki pola yang berbeda juga bila dibandingkan dengan laju pada perendaman 18 jam. Pada perendaman 18 jam laju imbibisi tertinggi terdapat pada perendaman dengan air panas $(0,022 \mathrm{~mL} / \mathrm{jam})$, sedangkan pada perendaman 24 jam laju tertinggi terdapat pada pengalasan penuh $(0,037 \mathrm{~mL} / \mathrm{jam})$.

Setelah perendaman 24 jam laju imbibisi biji yang diamplas penuh memiliki laju yang sama dengan asam kuat $\mathrm{HCl}$ yaitu sebesar $0,038 \mathrm{~mL} / \mathrm{jam}$. Bila dilihat secara umum laju imbibisi pada perendaman 24 jam lebih tinggi dibandingkan dengan perendaman 18 jam maupun perendaman 36 jam pada semua perlakuan kecuali kontrol, namun memiliki pola yang hampir mirip pada setiap perlakuannya. 


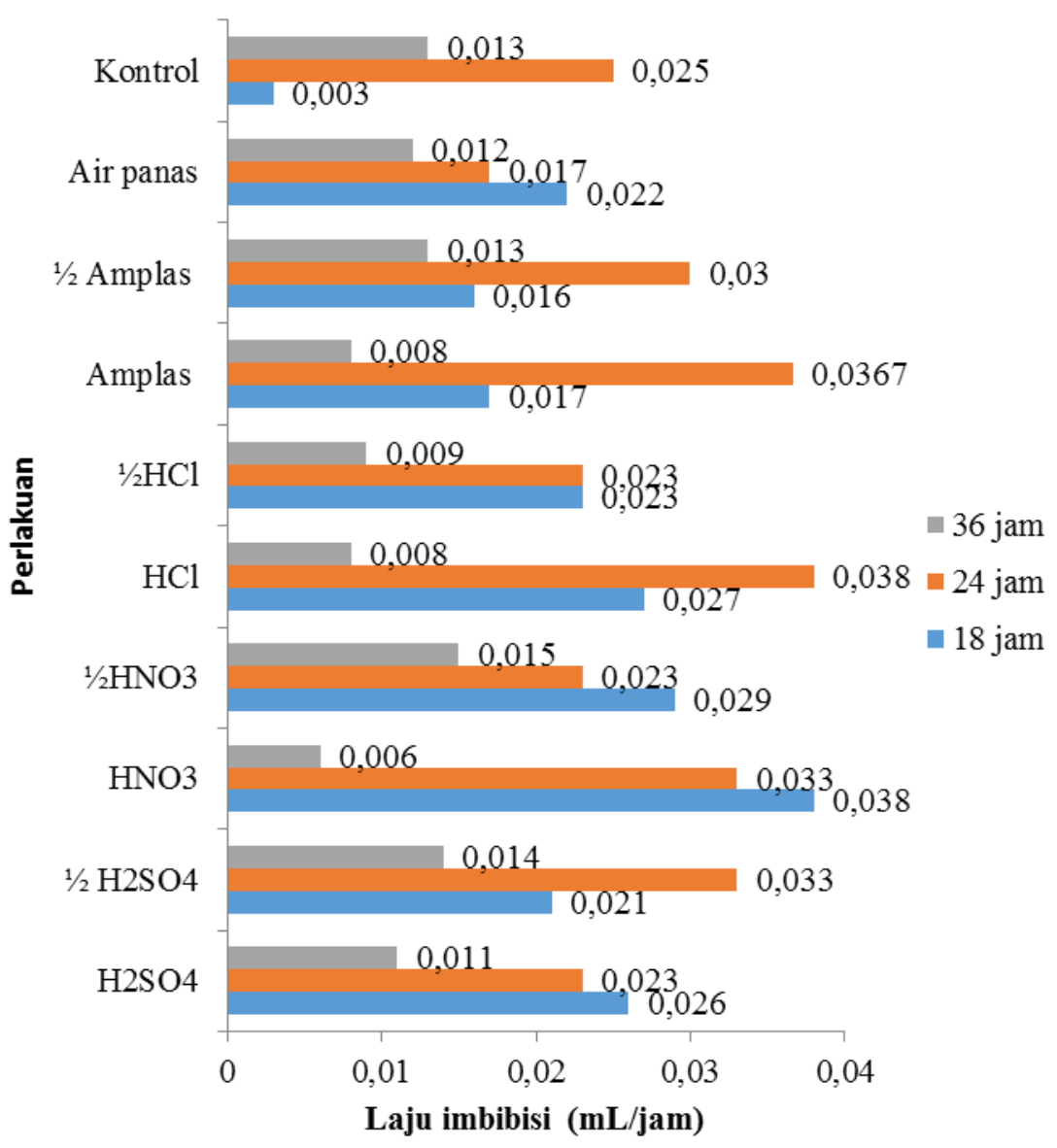

Gambar 3. Rata-rata laju imbibisi air pada biji aren yang diberi berbagai perlakuan

Tabel 1. Daya kecambah biji aren yang direndam dengan asam kuat, diamplas, air panas dengan waktu perendaman yang berbeda pada 7 dan 9 minggu setelah tanam (MST)

\begin{tabular}{|l|c|c|c|c|c|c|}
\hline \multirow{2}{*}{ Waktu Perendaman } & \multicolumn{2}{|c|}{18 jam } & \multicolumn{2}{c|}{24 jam } & \multicolumn{2}{c|}{36 jam } \\
\cline { 2 - 7 } Perlakuan & 7 MST & 9 MST & 7 MST & 9 MST & 7 MST & 9 MST \\
\hline $1 \mathrm{M} \mathrm{H}_{2} \mathrm{SO}_{4}(\%)$ & & & & & & \\
$0,5 \mathrm{M} \mathrm{H}_{2} \mathrm{SO}_{4}(\%)$ & 66,67 & 100,00 & 66,67 & 66,67 & 33,33 & 33,33 \\
$1 \mathrm{M} \mathrm{HNO}_{3}(\%)$ & 66,67 & 100,00 & 66,67 & 66,67 & 66,67 & 66,67 \\
$0,5 \mathrm{M} \mathrm{HNO}(\%)$ & 33,33 & 66,67 & 33,33 & 66,67 & 33,33 & 33,33 \\
$1 \mathrm{M} \mathrm{HCl}(\%)$ & 100,00 & 100,00 & 33,33 & 66,67 & 33,33 & 33,33 \\
$0,5 \mathrm{M} \mathrm{HCl}(\%)$ & 66,67 & 66,67 & 66,67 & 66,67 & 66,67 & 66,67 \\
Amplas Penuh(\%) & 66,67 & 66,67 & 66,67 & 66,67 & 66,67 & 66,67 \\
Amplas (1/2 bagian)(\%) & 66,67 & 66,67 & 66,67 & 100,00 & 66,67 & 66,67 \\
Air Panas (\%) & 33,33 & 66,67 & 66,63 & 66,67 & 66,67 & 66,67 \\
Kontrol & 0,00 & 33,33 & 33,33 & 66,67 & 33,33 & 66,67 \\
\end{tabular}

\section{Laju Perkecambahan Biji Aren}

Pada penelitian ini biji aren yang diberi berbagai perlakuan dan lama perendaman yang bervariasi seperti pada tabel 1 mulai berkecambah pada 7 minggu setelah tanam (MST). Jumlah biji atau presentasi biji yang berkecambah bervariasi. Pada kontrol hingga umur 9 MST tidak mampu berkecambah atau daya kecambah $0 \%$. Perlakuan fisik dan kimia memiliki pengaruh yang hampir sama terhadap kemampuan biji berkecambah maupun presentasi biji yang berkecambah (33,33-100\%). Biji yang diamplas penuh memiiki daya kecambah lebih cepat dan lebih besar dibandingkan yang diamplas sebagian. Perbedaan jenis dan konsentrasi asam kuat yang diberikan mempengaruhi daya kecambah. Konsentrasi asam kuat yang lebih rendah $(0,5 \quad \mathrm{M})$ 
cenderung memiliki daya kecambah yang lebih besar dibandingkan dengan konsentrasi yang lebih tinggi (1 M). Biji yang direndam dengan asam kuat selama 18 jam cenderung memiliki daya kecambah yang lebih tinggi dibandingkan dengan waktu perendaman 24 maupun 36 jam (Tabel 1).

Perbedaan persentasi kecambah maupun kecepatan perkecambahan biji aren dalam penelitian ini diduga berhubungan dengan volume air yang masuk ke dalam biji sehingga dapat memperpendek masa dormansi dan merangsang biji untuk berkecambah. Pada perendaman $0,5 \mathrm{M} \mathrm{HNO}_{3}$ selama 18 jam relatif memiliki waktu perkecamban lebih cepat (7 minggu) dengan persentasi biji berkecambah hingga $100 \%$. Perlakuan fisik dengan pengamplasan penuh dengan lama perendaman 24 jam memiliki presentase biji berkecambah hingga $100 \%$, namum waktu perkecambahan relatif lebih lama dibandingkan dengan $0,5 \mathrm{M}$ $\mathrm{HNO}_{3}$.

\section{PEMBAHASAN}

Imbibisi merupakan tahap pertama yang sangat penting dalam perkecambahan yang mengakibatkan peningkatan kandungan air dalam benih sehingga memicu perubahan biokimiawi dalam benih. Terhambatnya imbibisi akan mengakibatkan terhambatnya proses perkecambahan. Hal tersebut diduga mengakibatkan biji aren di alam memiliki masa dormansi hingga beberaapa tahun sebelum berkacambah. Kulit biji yang keras dan tebal pada biji aren mengakbatkan terhambatnya imhibisi yang berakibat pada lamanya waktu perkecambahan.

Pada penelitian ini ditemukan bahwa biji aren kontrol pada 18 jam perendaman hanya mampu menyerap air sebesar $0,06 \mathrm{~mL}$ air atau dengan laju imbibisi sebesar $0,003 \mathrm{~mL} / \mathrm{jam}$. Hal menunjukkan bahwa biji aren mampu menyerap air dengan laju yang sangat rendah, disebabkan adanya lapisan luar kulit biji yang mengandung kutikula dan atau jaringan epidermis yang dibangun oleh macrosclereids (De Souza \& Marcos-Filho, 2001, Ma et al., 2004, Qutob et al., 2008), yang merupakan komponen yang bersifat hidrophobik yang mengakibatkan air sulit menembus kulit biji.

Proses perkecambahan dimulai dengan ketika biji dorman mulai menyerap air atau yang disebut dengan imbibisi. Imbibisi akan memacu sel dan laju metabolismeuntuk masuk ke dalam fase perkecambahan, namun proses selanjutnya akan dipengaruhi/dipacu oleh berbagai faktor eksternal seperti cahaya dan temperatur (Webb et al., 2009). Selain faktor eksternal ternyata perkecambahan juga dipengaruhi oleh faktor internal biji khusunya kandungan hormon biji seperti kandungan (ABA) dan asam gliberelin (GAs) (Finkelstein et al., 2008).

Mematahkan dormansi untuk menginisiasi perkecambahan dapat dilakukan dengan merusak kulit biji yang bertindak sebagai barrier (penghalang) imbibisi (Schutz, 2000). Perkecambahan melibatkan serangkaian kejadian yang dimulai dengan imbibisi (Varela \& Albornoz, 2013). Difusi air dan gas ke dalam biji dipengaruhi oleh struktur anatomi dan kimia dari kulit (De Souza \& MarcosFilho, 2001, Ma et al., 2004, Qutob et al., 2008). Kulit biji dapat dikategorikan sebagai biji yang bersifat permiabel atau impermiabel tergantung pada daya serapnya terhadap air (Varela \& Albornoz, 2013). Biji yang permiabel memiliki kulit biji yang "soft" sehingga biji menyerap air dengan cepat, sebaliknya biji yang keras (hard) tidak dapat melewatkan air ke dalam setelah beberapa hari atau minggu dan tetap dorman (Ma et al., 2004, Shao et al., 2007). Kulit biji keras merupakan mekanisme tumbuhan agar tetap survival (Varela \& Albornoz, 2013) terhadap tekanan yang datang dari lingkungan sekitar.

Biji yang masak secara fisiologis, tersusun oleh kulit benih (testa), endosperma, dan embrio. Jaringan testa tersusun oleh sel-sel sklereid sedangkan jaringan endosperma dan embrio tersusun oleh sel-sel parenkim. Jaringan testa benih merupakan jaringan mati, sedangkan jaringan endosperm sebagian selnya bersifat hidup. Kandungan air benih aren ketika dipanen relatif tinggi yaitu $(25-30 \%)$ (Widyawati et al., 2009). Hasil pengamatan (Widyawati et al., 2009) terhadap kadar lignin dan tanin benih menunjukkan bahwa semakin tua benih aren, kadar senyawa tersebut semakin meningkat. Jika dihubungkan antara kandungan lignin dan tanin benih dengan besarnya imbibisi ternyata terdapat korelasi erat yang bersifat negatif, berarti bahwa semakin tinggi kandungan lignin dan tanin biji 
aren, semakin rendah imbibisinya. Peningkatan kadar lignin dan tanin tersebut sangat berperan dalam menurunkan permeabilitas benih aren terhadap air.

Pada umumnya kulit benih yang tersusun oleh lignin, tanin, lilin dan sel sklereid yang rapat, dapat mengurangi sifat permeabilitasnya terhadap air. Fase hidrasi, testa sering menjadi faktor pembatas, sehingga penghilangan atau pengelupasan testa secara menyeluruh atau sebagian dapat mempercepat laju penyerapan air (Ellery \& Chapman, 2000). Testa merupakan struktur penting sebagai barier pelindung embrio dari lingkungan eksternal, mengendalikan penyerapan air dan pertukaran gas, serta sebagai hambatan mekanis keluarnya inhibitor dari embrio (Miao et al., 2001).

Temperatur mempengaruhi laju imbibisi pada biji (Jennings \& Saltveit, 1994). Biji yang diuji dengan suhu yang lebih tinggi memiliki laju imbibisi yang lebih tinggi dibandingkan dengan suhu yang lebih rendah. Dalam penelitian ini terlihat bahwa laju imbibisi pada biji aren memiliki laju imbibisi lebih tinggi dibandingkan dengan kontrol maupun pengamplasan. Miranda et al. (2010) menyatakan bahwa laju imbibisi pada biji dapat ditingkatkan dengan perendaman dengan larutan yang mengandung garam seperti $\mathrm{NaCl}$. Varela dan Albornoz (2013) biji yang memiliki kulit yang keras memiliki jaringan epidermis bagaian luar ditutupi dengan kutikula dan disusun oleh makroskereid. Bagian epidermis sebelah dalam disusun oleh jaringan osteosclereids, parenchyma, dan macrosclereids yang mengalami penebalan dinding sekunder.

Pada penelitian ini laju imbibisi biji aren terus meningkat hingga perendaman 24 jam (Gambar 1), namun mengalami penurunan pada waktu perendaman yang lebih lama (36 jam). Hal tersebut diduga bahwa biji sudah melewati kapasitas optimum untuk menyerap air pada waktu perendaman yang lebih lama. Varela dan Albornoz (2013) menyatakan bahwa laju imbibisi pada Anadenanthera colubrina (Fabaceae) meningkat hingga jam ke-24.

Pada penelitian ini laju imbibisi biji pada perlakuan asam kuat $\left(\mathrm{HNO} 3, \mathrm{H}_{2} \mathrm{SO}_{4}\right.$ dan $\left.\mathrm{HCl}\right)$ menunjukkan laju imbibisi lebih tinggi dibandingkan perlakuan lainnya pada perendaman
18 jam sejalan dengan laju perkecambahan. Masuknya air ke dalam biji diduga akan mengaktifkan enzim-enzim yang dibutuhkan dalam perkecambahan. Dalam penelitian ini perlakuan fisik dan kimia memiliki pengaruh yang hampir sama terhadap kemampuan biji berkecambah maupun presentasi biji yang berkecambah $(33,33-100 \%)$. Hal yang senada ditemukan Varela dan Albornoz (2013) menyatakan bawa asam kuat akan merusak jaringan luar kulit biji sehingga menghasilkan lubang-lubang kecil sebagai jalan masuknya air ke dalam biji, yang akan mematahkan masah dormansi.

\section{KESIMPULAN}

Biji aren yang diberi perlakuan fisik maupun kimia mengalami pengelupasan kulit biji. Laju imbibisi aren pada perendaman 24 jam lebih tinggi dibandingkan dengan lama perndaman 18 maupun 36 jam. Laju imbibisi tertinggi terjadi pada waktu perendaman $1 \mathrm{M}$ $\mathrm{HCl}$ dan amplas penuh dengan lama perendaman 24 jam sebesar $0,038 \pm 0,002$ $\mathrm{mL} / \mathrm{jam}$ dan $0,038 \pm 0,007 \mathrm{~mL} / \mathrm{jam}$ secara berturut-turut. Biji aren yang diberi perlakuan fisik dan kimia mulai berkecambah 7 minggu setelah tanam (MST) dengan daya kecambah tertinggi pada pemberian $\mathrm{HNO}_{3}$ dan lama perendaman 18 jam.

\section{REFERENSI}

Ali, H. H., Tanveer, A., Nadeem, M. A., \& Asghar, H. F. (2011). Methods to break seed dormancy of Rhynchosia capitata, a summer annual weed chilean. Journal of Agricultural Research, 71(3), 483-487.

Abu Bakar, Z., \& Maimuna. (2013). Effect of hydrochloric acid, mechanical scarification, wet heat treatment on germination of seed of Parkia Biglobosa african locust bean (Daurawa) case study of gombe local government area. Journal of Applied Sciences and Enviromental Management, 17(1), 119-123.

Cavalheiro, A. L., Pimenta, J. A., \& Torezan, J. M. D. (2007). Effect of some physical and chemical treatments on germination of Colubrina glandulosa seeds. Seed Science and Technology, 35, 744-748.

Cutler, A. J., \& Krochko, J. E. (1999). Formation and breakdown of ABA. Trends in Plant Science, 4(12), 472-478. 
Ellery, A. J., \& Chapman, R. (2000). Embryo and seed coat factors produce seed dormancy in cape weed (Artctotheca calendula). Australian of Journal Agricultural Research, 51, 849-854.

De Souza, F. H. D., \& Marcos-Filho, J. (2001). The seed coat as a modulator of seedenvironment relationship in Fabaceae. Revista Brasiliera de Botanica, 24, 365375.

Ferita, I., Tawarati, \& Syarif, Z. (2015). Identifikasi dan karakterisasi tanaman enau (Arenga pinnata) di Kabupaten Gayo Lues. Prosiding Seminar Nasional Masyarakat Biodiversitas Indonesia, 1(1), 31-37.

Finch-Savage, G. W. E., \& Leubner-Metzger, G. (2006). Seed dormancy and the control of germination. New Phytologist, 171, 501-523.

Finkelstein, R., Reeves, W., Ariizumi, T., \& Steber, C. (2008). Molecular aspects of seed dormancy. Annual Review of Plant Biology, 59, 387-415.

Graeber, K., Nakabayashi, K., Miatton, E., Leubner-Metzger, G., \& Soppe, W. J. J. (2012). Molecular mechanisms of seed dormancy. Plant Cell and Environment, 35, 1769-1786.

Jennings, P., \& Saltveit, M. E. (1994). Temperature Effects on Imbibition and Germination of Cucumber (Cucumis sativus) Seeds. Journal of the America Sociaty for Horticultural Science, 119(3), 464-467.

Koorneef, M., Bentsink, L., \& Hilhorst, H. (2002). Seed dormancy and germination. Current Opinion in Plant Biology, 5, 3336.

Lasut, M. T. (2012). Budidaya yang baik aren (Arenga pinnata (Wurmb) Merr.). Kerjasama Fakultas Pertanian Universitas Sam Ratulangi dan Universitas Texas.

Ma, F., Cholewa, E., Mohamed, T., Peterson, C. A., \& Gijzen, M. (2004). Craks in the palisade cuticule of soybean seed coats correlate with their permeability to water. Annal of Botany, 94, 213-228.

Mashud, N., Rahman, R., \& Maliangkay, R. B. (1989). Pengaruh berbagai perlakuan fisik dan kimia terhadap perkecambahan dan pertumbuhan bibit aren. Jurnal Penelitian Kelapa, 4(1), 27- 37.

Martini, E., Roshetko, J. M., van Noordwijk, M., Rahmanulloh, A., Mulyoutami, E., Joshi, L., \& Budidarsono, S. (2012). Sugar palm (Arenga pinnata (Wurmb) Merr.) for livelihoods and biodiversity conservation in the orangutan habitat of Batang Toru, North Sumatra, Indonesia: mixed prospects for domestication. Agroforestry System, 86(3), 401-4017.

Miao, Z. H., Fortune, J. A., \& Gallagher, J. (2001). Anatomical structure and nutritive value of lupin seed costs. Australian Journal Agricultural Research 52, 985-993.

Miranda, D., Ulrichs, C., \& Fischer, G. (2010). Imbibition and percentage of germination of cape gooseberry (Physalis peruviana L.) seeds under $\mathrm{NaCl}$ stress. Agronomía Colombiana, 28(1), 29-35.

Qutob, D., Ma, F., Peterson, C. A., Bernards, M. A., \& Gijzen, M. (2008). Structural and permeability properties of the soybean seed coat. Botany, 86, 219-227.

Saleh, M. S. (2004). Pematahan dormansi benih aren secara fisik pada berbagai lama ekstraksi buah. Agrosains, 6(2), 7983.

Schulz, W. (2000). Ecology and seed dormancy and germination in sedges (Carex) perspectives in plant ecology. Evolution and Systematics, 3, 67-89.

Shao, S., Meyer, C. J., Ma, F., Peterson, C. A., \& Bernards, M. A. (2007). The outermost cuticle of soybean seeds: chemical composition and function during imbibition. Journal of Experimental Botany, 58, 1071-1082.

Tamrin, Y., Sukarno, A., \& Kusumawardani, N.D. (2015). Studi pemanfaatan pohon aren (Arenga pinnata Merr), 1-11. Retrived 2 Februari 2016 pukul 14.00.

Webb, J., Miao, S., \& Zhang, X. (2009). Factors and mechanisms influencing seed germination in a wetland plant sawgrass. Plant Growth Regulation, 57, 243-250. 
Widyawati, N., Tohari, Yudono, P., \& Soemardi, I. (2009). Permeabilitas dan perkecambahan benih aren (Arenga pinnata (Wurmb.) Merr.). Journal Agronomi Indonesia, 37(2), 152-158.
Varela, R. O., \& Albornoz. (2013). Morphoanatomy, imbibition, viability and germination of the seed of Anadenanthera colubrina var. cebil (Fabaceae). Revista de Biologia Tropica, 61(3), 1109-1118. 